ISSN 2519-2523 (print)

DOI: $10.18524 / 2519-2523.2020 .15 .218678$

УДК 94:070:377.8(477.74-21) “1827/1894”

\title{
NEWSPAPER «ODESSA HERALD» (1827-1894) AS A HISTORICAL SOURCE ON THE HISTORY OF THE ODESSA INSTITUTE OF NOBLE MAIDEN
}

\author{
Anna Korobchuk \\ ORCID: https://orcid.org/0000-0001-9125-7036 \\ Post-graduate student at the Department of Ukrainian History \\ Odessa I.I. Mechnikov National University \\ 2, Dvoryanska Str., Odesa, 65082, Ukraine \\ korobcukanna@gmail.com
}

The purpose of the article is to analyze source information in newspaper "Odessa Herald» to study the topic "History of the Odessa Institute of Noble Maiden". A phenomenon in the education system of the Russian Empire XVIII-XIX century there was the emergence of women's schools, institutes of noble maiden. Odessa Institute of Noble Maiden was a closed privileged educational establishment in the south of the Russian Empire, which belonged to the 1 st. level of the department of Empress Maria establishments. Beginning in 1827, the "Odessa Herald» was published twice a week in French (Journal d'Odessa) and Russian. It is important that the existence of the edition coincides with a significant period of operation of the Institute (65 years). The scientific novelty is that for the first time a search was conducted on the above topics in one of the leading local edition. The author carried out a frontal review of the "Odessa Herald" for 18291890. On the pages of the newspaper were found 200 notes reflecting the history of the Institute. Publications were divided into two groups: 1. News, 2. Announcements. The research methods are based on the main principles of historicist tradition, scientific objective, comprehensive approach and data classification. In order to achieve the purpose, the author uses a number of general scientific methods (analytic, synthesis, classification) as well as specific historical methods, such as problematic and chronological, comparative and method of periodization. The newspaper "periodically covered the news and announcements of the Institute, which aimed to inform parents, relatives and the public about past ceremonial events, changes in functioning, as well as the urgent needs of the school. At different times, they found their prominent place in various sections: "Inside", "Messages", "Local Chronicle", "Announcements". The materials in the "Announcements" section are the most quantitative, but insignificant for the study of the history of the Institute. Periodic articles on the issue of boarding houses, which were quite extensive in scope, are important for reproducing the lists of students of the Institute, household, etc. moments related to the functioning of the educational institution. Thus, the publications in the "Odessa Herald» are an auxiliary source on the history of the Odessa Institute of Noble Maiden. They complement the existing archives and those related to the functioning of the educational institution.

Key words: "Odessa Herald», noble Maiden institutes, women's education, nobleness, comprehensive education, the South Ukraine, department of Empress Maria establishments, closed girl's boarding schools.

Анна Коробчук

ORCID: https://orcid.org/0000-0001-9125-7036

Аспірантка кафедри історії України Одеський національний університет імені I.I. Мечникова Вул. Дворянська, 2, Одеса, 65082, Україна korobcukanna@gmail.com 


\section{ГАЗЕТА “ОДЕССКИЙ ВЕСТНИК” (1827-1894) ЯК ІСТОРИЧНЕ ДЖЕРЕЛО З ІСТОРІЇ ОДЕСЬКОГО ІНСТИТУТУ ШЛЯХЕТНИХ ДІВЧАТ}

Метою статті є аналіз джерелознавчої інформації на шпальтах газети «Одесский вестник» для вивчення теми «Історія Одеського інституту иляхетних дівчат». Наукова новизна полягає в тому, щзо вперше було здійснено пошук за даною тематикою в одному з провідних місиевих видань. Отже, публікації в «Одесском вестнике» $\epsilon$ допоміжним джерелом з історї Одеського інституту шляхетних дівчат. Статті в газеті «Одесский вестник» доповнюють наявні архівні та статистичні документи, щуо стосуються функціонування закладу освіти. Газета періодично висвітлювала новини та оголошення Інституту. У різний час вони знаходили своє місце в різних рубриках: "Внутрішні відомості», «Повідомлення», «Місцева хроніка», «Оголомення».

Ключові слова: "Одесский вестник», Одеський інститут иляхетних дівчат, Відомство установ імператрииі Марії, Одеське міське дівоче училище, Рада інституту иляхетних дівчат.

На початку модерної доби характерною рисою системи освіти Російської імперії кінця XVIII - початку XIX ст. стала поява жіночих закладів освіти, зокрема інститутів шляхетних дівчат [29]. Одеський інститут шляхетних дівчат (далі інститут) - закритий привілейований заклад освіти (длі - 30) на півдні Російської імперії, який належав до першого розряду відомства установ імператриці Марії [17, c. 8]. Інформація щодо історії установи розпорошена по різноманітних джерелах, одним із яких є матеріали тогочасної преси.

Періодичні видання вміщують цілий комплекс багатоманітної інформації й $є$ корисними під час вивчення різної проблематики. Ключова позитивна специфіка періодики як історичного джерела - близькість до подій [16]. Одним із таких унікальних видань є газета «Одесский вестник» (далі - ОВ) [16, с. 405].

Серед сучасних дослідників ОВ комплексним характером вирізняється дисертаційне дослідження Г. С. Левченко «Газета "Одесский вестник" (1827-1894): внесок у розвиток історичного краєзнавства на півдні України» [18]. Дослідниця звертає увагу, що зазначене вище видання $є$ джерелом інформації 3 цілої низки краєзнавчих питань $[18$, с. 30]. Через це фахівці 3 історії півдня України: І. С. Гребцова [12], Т. Г. Гончарук [10], Н. М. Діанова [13], В. В. Левченко [19], Л. В. Новікова [22], О. О. Синявська [11], В. М. Хмарський [30] та ін. залучають матеріали місцевої преси для дослідження краєзнавчої проблематики.

Газета ОВ, починаючи 31827 р. випускалась двічі на тиждень, французькою («Journal d'Odessa») та російською мовами [25]. Прикметно, що час існування видання збігається зі значним періодом функціонування Інституту (65 років).

Здійснювався фронтальний перегляд ОВ за 1829-1890 рр. На сторінках газети віднайдені 200 заміток, що відображають історію розвитку інституту. Публікації доцільно поділити на дві групи: 1. Новини про заклад освіти (розміщувалися в рубриках «Внутрішні відомості», «Повідомлення», «Хроніка» («Місцева хроніка»); 2. Оголошення (розміщувалися в рубриці «Оголошення»). Подані замітки на шпальтах газети відповідно у співвідношенні 50 на 50\%.

Найбільша концентрація статей про інститут сягає 1828-1854 рр. Впродовж цих років публікації були найбільш значними за обсягом, а відповідно інформативнішими. У публікаціях не зазначено авторство, але примітним є те, що в період 1829-1832 рр. О. Г. Тройницький викладав в інституті історію і географію, а 
згодом був інспектором класів. Паралельно він працював кореспондентом ОВ, а 3 1834 р. головним редактором [21, с. 76].

У рубриці «Внутрішні відомості» за 21 серпня 1829 р з'явилась перша публікація про 30 - 28 липня 1829 р. установу прийнято під протекторат Відомства установ імператриці Марії (далі - ВУІМ). 26 квітня 1830 р. в ОВ опубліковано новину, яка сповіщала про призначення та приїзд до міста нової директорки Інституту Луїзи Сукової [9, с. 133]. Непересічним в інституті було свято «Тезоіменитство» (іменини царської особи) імператриці Олександри Федорівни (дружина Миколи I, мати Олександра II), яке урочисто святкувалося вихованками та знатними гостями щороку 23 квітня. Про традиційний церемоніал засвідчують новини наступного дня у рубриці «Внутрішні відомості». На шпальтах газети відображалися переліки заходів серед яких: божественна літургія та молебень в інститутській церкві та вечірні гуляння. Серед почесних гостей заходів були генерал-губернатор граф М. С. Воронцов, одеський градоначальник О. І. Льовшин [6, с. 129].

Інститут суворо контролював правила внутрішнього розпорядку закладу. Проте за межами закладу закритої установи знаходилися батьки та родичі вихованок, які певною мірою робили внесок у виховання дівчат власним прикладом. Через це, Рада інституту публікувала оголошення, що стосувалися правил приватних візитів на шпальтах OB [8, c. 314$]$.

ОВ повідомляв про структурні зміни інституту, що відбулися у 1835 p. Першочергову роль в установленні зв'язків інституту відігравала належність закладу до ВУІМ. У 1835 р. під відомчий контроль було прийнято Одеське міське дівоче училище. Історія цього заклада овіти розпочинається з 1817 р., а його функціонування $\epsilon$ важливою віхою у становленні жіночої освіти на півдні України. У період 1817-1835 pp. контроль над навчальним процесом здійснював Рішельєвський ліцей [26]. Новий устав училища зайняв своє місце на першій сторінці ОВ [5, с. 401] за 1835 р. Важливо, що згідно $3 \S 2$ навчальний заклад мав підпорядковуватись Раді інституту й безпосередньо відомству імператриці. Рада інституту отримала фінансовий контроль над закладом, але об'єднувати гроші двох установ заборонялося (§19) [5, с. 401-402].

Головною подією, яка відзначалася помпезністю в інституті були випуски вихованок. На початку існування установи вони проходили кожні два роки 1 липня. Ця подія заслуговувала на розміщення подробиць заходу на велику статтю в місцевих виданнях. Підбиття підсумків навчання вперше повідомлялось на сторінках ОВ [7, c. 209-210].

В інституті під час кожного випуску відзначали найкращих вихованок, які за відмінні знання та зразкову дисципліну отримували нагороди під час урочистостей. Такими нагородами були: золотий вензель (інша назва - «шифр») імператриці, золота медаль, срібна медаль та похвальні листи. Важливо, що при уніфікованій системі нагород кожен відомчий заклад вирізнявся кольором стрічки. Публікації про випуски інформують, що кращі випускниці Інституту носили свій Золотий вензель на лівому плечі, на білій стрічці з блакитними окрайками [2, с. 297].

На сторінках ОВ за 1837 р. було опубліковано заповіт відставного полковника Курта: «О пожертвовании движимого и недвижимаго имения, в пользу Одесскаго института благородных девиц отставным полковником Куртом» [23, с. 694-695]. Прибутки 3 отриманого володіння давали шанс на освіту збіднілим та осиротілим дворянкам. У 1848 р. розпочався процес реорганізації освітнього процесу в інститутах. В одній із публікацій ОВ зазначалось, що всі вихованки закладу були поділені відповідно на два класи - старший та молодший, в кожному з них було два 
паралельних відділення, курс навчання мав тримати три роки. Прослідковується тенденція поступового збільшення кількості інституток, шо свідчило про зростання престижності жіночої освіти в регіоні. Того ж року, відбувся випуск 50 пансіонерок [17], що вдвічі більше, аніж десять років потому [3, с. 307-308].

Починаючи 31851 р. на шпальтах ОВ з'явилися оголошення зі списком претенденток на заміщення 11 вакантних місць в інституті [28]. Через кілька номерів, Рада інституту розміщує інформацію про тих, кому пощастило за жеребкуванням стати вихованками закладу. Проте дані оголошення не містять інформації до якого класу їх було зараховано чи хоча б вік дівчат.

Починаючи 31872 p. новини, які стосувалися різнобічних моментів функціонування установи розміщували в рубриці «Повідомлення», яка знаходилася на першій сторінці номера. Цього року було опубліковано новину про двадцять четвертий випуск інституту, який налічував 34 пансіонерки. Порівнюючи 3 публікаціями про перші випуски закладу, то замітка 1872 p. вирізняється лаконічністю. В ній перераховані всі випускниці, а окремо вихованки з відзнаками [14, с. 559].

ОВ від моменту заснування закладу публікувала в рубриці «Оголошення» запрошення від імені Рада інституту на торги до інституту, які були присвячені поставці необхідних промислових та побутових товарів. Головна тенденція розміщення подібних оголошень - повторна публікація (2-3 рази) у наступних випусках видання. Щорічно в ОВ під кінець або на початку календарного року 3'являлися переліки необхідних закупівель для закладу: дров, тканини, предметів побуту.

31871 р. актуальності набирали новини, які мали на меті сповіщення батьків та родичів про прийом нових дівчат до навчального закладу, канікули вихованок, проведення іспитів [15, с. 1].

29 грудня 1879 р. Одеський інститут шляхетних дівчат відзначав важливу подію - п’ятдесятирічний ювілей свого існування. До цієї події було опубліковано «Краткий исторический очерк пятидесятилетия Одесского института благородных девиц» [17]. Подробиці святкування заходу були опубліковані достатньо докладно на першій сторінці в ОВ за 1880 р. У публікації повністю процитовано головну промову церемонії, які оголосила пансіонерка старшого класу Софія Гунаролуло [33, с. 1-2]. 3 нагоди свят у стінах інституту проходили бали. Поте новини про них не потрапляли на шпальти ОВ. Винятково, у 1884 р. ОВ було зафіксовано про один 3 ошатніших балів у закладі. [24, с. 1].

На сторінках видання ОВ за 1890 р. оголошення, які повідомляли батьків та родичів про канікули та випуск вихованок було розміщено у рубриці «Місцева хроніка» [20, с. 3] на третій сторінці газети, що робило їх менш помітними та формальними. У 1880 р. у рубриці «Хроніка» [31, с. 2], яка розміщувалася на другій сторінці видання, знаходилось місце для повідомлень про балотування на заміщення вакантних пансіонерок, а у 1885 р. [32, с. 3] опубліковано новину про необхідність капітального ремонту будівлі.

Отже, ОВ періодично висвітлювала новини та оголошення інституту, які мали на меті повідомляти родичів вихованок та громадськість про минулі урочисті заходи, зміни у функціонуванні, а також нагальні потреби 30. У різний час вони знаходили місце в різних рубриках: «Оголошення», «Внутрішні відомості», «Повідомлення», «Місцева хроніка». Матеріали, розміщенні рубриці «Оголошення» $є$ найбільш кількісними, але малозначущими для дослідження історії Інституту. Періодичні статті 
про випуски пансіонерок, які були достатньо значними за обсягом є важливими для відтворення переліків вихованок Інституту, побутових та інших моментів, пов'язаних 3 функціонуванням 3О. Відповідно, публікації в ОВ являють собою допоміжне джерело з історії Одеського інституту шляхетних дівчат. Статі в газеті доповнюють наявні архівні та, що стосуються функціонування закладу освіти.

\section{Джерела та література:}

1. Внутреннія известія, Одесса, 21-го Августа // Одесский вестник (далі ОВ). - 1829. - №67. C. 281.

2. Внутреннія известія, Одесса, 23-го Іюля. // ОВ. - 1846. - №59. - С. 297.

3. Внутреннія известія, Одесса, 23-го Іюля // ОВ. - 1848. №59. - С. [307-308].

4. Внутреннія известія, Одесса, 30-го Ноября. // ОВ. - 1862. - №130. - С. 591.

5. Внутреннія известія. Одесса, 17-го Декабря // ОВ. - 1835. - №101. - С. 401-402.

6. Внутреннія известія. Одесса, 24-го Апреля // ОВ. - 1834. - №33. - С. 129.

7. Внутреннія известія. Одесса, 2-го Іюля // ОВ. - 1832. - №53. - С. 209-210.

8. Внутреннія известія. Одесса, 3-го Октября // ОВ. - 1834. - №79. - С. 314.

9. Внутреннія известія. Одесса, 26-го Апреля // ОВ. - 1830. - №34. - С. 133.

10. Гончарук Т. Г. Інформація про українські видання на сторінках газети "Одесский вестник" 1830-х - першої половини 1840-х рр.: від оголошень до рецензій / Т. Г. Гончарук // Інтелігенція і влада. Серія : Історія. - 2013. - Вип. 28. - С. 159-166.

11. Гончарук Т. Г. "Одесский вестник" про недільні школи початку 1860-х рр. / Т. Г. Гончарук, О. О. Синявська // Записки історичного факультету. - 2004. - Вип.15. - С. 408-422.

12. Гребцова И. С. Периодическая печать: в общественном развитии Южного степного региона Российской империи (Вторая треть ХІХ в.) / Гребцова И. С. - Одесса : Астропринт, 2002. - 408 с.

13. Діанова Н. Дослідження Науково-просвітницької діяльності архієпископа Інокентія (Борисова) в дореволюційній історіографії / Н. Діанова // Історіографічні дослідження в Україні: Зб. наук. пр. 2013. - Вип. 23. - С. 93-102.

14. Извещенія. От совета Одесскаго института благородных девиц // ОВ. - 1872. - №138. - С. 559.

15. Извещенія. Совет Одесскаго института благородных девиц // ОВ. - 1874. - №85. - С. 1.

16. Історичне джерелознавство / Я. С. Калакура, І. Н. Войцехівська, С. Ф. Павленко, Б. І. Корольов, М. Г. Палієнко; гол. ред. С. В. Головко. - К.: Либідь, 2002. -488 с.

17. Краткий исторический очерк пятидесятилетия Одесского Института благородных девиц. - Одесса, 1879. -44 c.

18. Левченко Г. С. Газета "Одесский вестник" (1827-1894): внесок у розвиток історичного краєзнавства на Півдні України : дис ... канд. іст. наук / Галина Сергіївна Левченко. - Одеса, 2017. $-373 \mathrm{c}$.

19. Левченко В. В. Олександро-Невська церква Новоросійського університету: історія, персоналії, документи / В. В. Левченко, Г. С. Левченко. - Одеса: ФОП Бондаренко М. О., 2015. - 360 с.

20. Местная хроника. // ОВ. - 1890. - №118. -С. 3.

21. Модзалевский В. Л. Тройницкие / В. Л. Модзалевский //Малороссийский родословник. - 1996. - Т. 5. Вып. 1. - С. 76-87.

22. Новікова Л. В. Святкування тисячоліття православної народної Болгарської церкви в Одесі, 3 травня 1870 р. / Л. В. Новікова // Юго-запад. Одессика=Південний Захід. Одесика : історикокраєзнавчий альманах. - 2016. - Вип. 21. - С. 77-88.

23. О пожертвовании движимого и недвижимого имения, в пользу Одесскаго института благородных девиц отставным полковником Куртом. // ОВ. - 1837. - №58. - С. 694-695;

24. Одесса, 15-го ноября. Бал в институте благородных девиц. // ОВ. - 1884. - №252. - С. 1.

25. ОВ. Энциклопедический словарь Брокгауза и Ефрона [Електронний ресурс]. - Режим доступа: https://ru.wikisource.org/wiki/ЭСБЕ/Одесский_Вестник. (дата 29.11.20). - Назва з екрану.

26. Одесское городское девичье училище (ул. Старопортофранковская, 32). 2015. [Електронний pecypc]. - Режим доступа: https://www.shukach.com/ru/node/44244 (дата 29.11.20). - Назва з екрану.

27. От Совета Одесского Института Благородных Девиц // ОВ - 1837. - №38. 
28. От Совета Одесскаго Института Благородных Девиц // ОВ. - 1851. - №48.

29. Поздняков А. Н. Институты благородных девиц в системе образования России второй половины XVIII начала XIX в. [Електронний ресурс]. / А. Н. Поздняков. - Режим доступа: https:/cyberleninka.ru/article/n/instituty-blagorodnyh-devits-v-sisteme-obrazovaniya-rossii-vtoroypoloviny-xviii-nachala-xix-veka/viewer (дата 29.11.20). - Назва з екрану.

30. Хмарський В. М. Археографічна діяльність Таврійської вченої архівної комісії наприкінці XIX - на початку XX ст. (1896-1909) / В. М. Хмарський // Записки історичного факультету. - 2004. Вип. 15. - С. 433-449.

31. Хроника. // ОВ. - 1880. - №156. - С. 2.

32. Хроника. Осмотр зданія института благородных девиц. // ОВ. - 1885. - №192. - С. 3.

33. Хроника. Пятидесятилетній юбилей Одесскаго института благородных девиц. // ОВ. - 1880. №1.

\section{References:}

1. Vnutrenniya izvestiya, Odessa, 21-go Avgusta, 1829. Odesskij vestnik, 67, s. 281. [in Russian]. 2. Vnutrenniya izvestiya, Odessa, 23-go Iyulya, 1846. Odesskij vestnik, 59, s. 297. [in Russian]. 3. Vnutrenniya izvestiya, Odessa, 23-go Iyulya, 1848. Odesskij vestnik, s. [307-308]. [in Russian]. 4. Vnutrenniya izvestiya, Odessa, 30-go Noyabrya, 1862. Odesskij vestnik, 130, s.591. [in Russian]. 5. Vnutrenniya izvestiya, Odessa, 17-go Dekabrya, 1835. Odesskij vestnik, 101, s. 401-402. [in Russian].

6. Vnutrenniya izvestiya, Odessa, 24-go Aprelya, 1834. Odesskij vestnik, 33, s.129. [in Russian]. 7. Vnutrenniya izvestiya, Odessa, 2-go Iyulya, 1832. Odesskij vestnik, 53 s. 209-210. [in Russian]. 8. Vnutrenniya izvestiya, Odessa, 3-go Oktyabrya, 1834. Odesskij vestnik, 79, s. 314. [in Russian]. 9. Vnutrenniya izvestiya, Odessa, Aprelya 26, 1830. Odesskij vestnik, 34, s. 133. [in Russian]. 10. Honcharuk, T. H., 2013. Informatsiia pro ukrainski vydannia na storinkakh hazety "Odesskij vestnik" 1830-kh-pershoi polovyny 1840-kh rr.: vid oholoshen do retsenzii. Intelihentsiia $i$ vlada, Seriia : Istoriia, 28, s. 159-166. [in Ukrainian].

11. Honcharuk, T. H. and Syniavska, O. O., 2004. "Odesskij vestnik" pro nedilni shkoly pochatku 1860-kh rr. Zapysky istorychnoho fakultetu, 15, s. 408-422. [in Ukrainian].

12. Hrebtsova, I. S., 2002. Periodicheskaya pechat': v obshchestvennom razvitii Yuzhnogo stepnogo regiona Rossijskoj imperii (Vtoraia tret 19 v.). Odessa: Astroprynt [in Russian].

13. Dianova, N. M., 2013. Doslidzhennia Naukovo-prosvitnytskoi diialnosti arkhiiepyskopa Inokentiia (Boryova) v dorevoliutsiinii istoriohrafii. Istoriohrafichni doslidzhennia v Ukraini: Zb. nauk. pr., 23, s. 93-102. [in Ukrainian].

14. Izveshcheniia. Ot soveta odesskago instituta blagorodnyh devic, 1872. Odesskij vestnik, 138, s. 559. [in Russian].

15.Izveshcheniya. Sovet Odesskago instituta blagorodnyh devic, 1874. Odesskij vestnik, 85, s.1. [in Russian].

16. Kalakura, I. S., 2002. Istorychne dzhereloznavstvo. Kyiv: Lybid'. [in Ukrainian].

17. Kratkij istoricheskij ocherk pyatidesyatiletiya Odesskogo instituta Blagorodnyh devic, 1879.. Odessa. [in Russian].

18. Levchenko, H. S., 2017. Hazeta "Odesskij vestnik" (1827-1894): vnesok u rozvytok istorychnoho kraieznavstva na Pivdni Ukrainy [The newspaper «Odessa Herald» (1827-1894): contribution to the development of local history in the south of Ukraine]. Ph.D. thesis, Odesa. [in Ukrainian].

19. Levchenko, V. V., 2015. Oleksandro-Nevska tserkva Novorosiiskoho universytetu: istoriia, personalii, dokumenty. Odesa: FOP Bondarenko M. O. [in Ukrainian].

20. Mestnaya hronika, 1890. Odesskij vestnik, 118, s. 3 [in Russian].

21. Modzalevs'kyj, V. L., 1996. Malorosïj'kyj rodoslovnyk, 5(1).[in Russian].

22. Novikova, L. V., 2016. Sviatkuvannia tysiacholittia pravoslavnoi narodnoi Bolharskoi tserkvy v Odesi, 3 travnia 1870 r. Yuho-zapad. Odessyka=Pivdennyi Zakhid. Odesyka : istorykokraieznavchyi almanakh, 21, s. 77-88. [in Ukrainian]. 
23. O pozhertvovanyy dvyzhymoho y nedvyzhymoho ymenyia, v polzu Odesskaho ynstytuta blahorodnыkh devyts otstavnыm polkovnykom Kurtom, 1837. Odesskij vestnik, 58, s. 694-695 [in Russian].

24. Odessa, 15-go noyabrya. Bal v institute blagorodnyh devic, 1884. Odesskij vestnik, 252, s. 1. [in Russian].

25. Odesskij Vestnik. Enciklopedicheskij slovar' Brokgauza i Efrona. [online]. Available at: $<$ https://ru.wikisource.org/wiki/ЭSBE/Odesskyi_Vestnyk> [Accessed 29 November 2020]. [in Russian].

26. Odesskoe gorodskoe devich'e uchilishche (ul. Staroportofrankovskaya, 32). [online]. Available at: <https://www.shukach.com/ru/node/44244> [Accessed 29 November 2020]. [in Russian].

27. Ot Soveta Odesskogo Instituta Blagorodnyh Devic, 1837. Odesskij vestnik, 38, s. 461. [in Russian].

28. Ot Soveta Odesskago Instituta Blagorodnyh Devic, 1851. Odesskij vestnik, 48 [in Russian].

29. Pozdnyakov, A. N. Instituty blagorodnyh devic v sisteme obrazovaniya Rossii vtoroj poloviny 18 nachala $19 v$. [online]. Available at: <https://cyberleninka.ru/article/n/instituty-blagorodnyhdevits-v-sisteme-obrazovaniya-rossii-vtoroy-poloviny-xviii-nachala-xix-veka/viewer> [Accessed 29 November 2020]. [in Russian].

30. Khmarskyi, V. M., 2004. Arkheohrafichna diialnist Tavriiskoi vchenoi arkhivnoi komisii naprykintsi 19 - na pochatku 20 st. (1896-1909). Zapysky istorychnoho fakultetu, 15, s. 433-449. [in Ukrainian].

31. Khronika, 1880. Odesskij vestnik, 156, s. 2. [in Russian].

32. Khronika, 1885. Osmotr zdaniya instituta blagorodnyh devic. Odesskij vestnik, 192, s. 3[in Russian].

33. Khronika, 1880. Pyatidesyatiletnij yubilej Odesskago instituta blagorodnyh devic. Odesskij vestnik, 1, s. 1-2. [in Russian].

Отримано: 29.11.2020 p. 